\title{
Cardiac misconceptions among healthy adults: implications for the promotion of health in the community
}

\author{
Crenças erróneas sobre as doenças cardíacas em adultos saudáveis: \\ implicações para a promoção da saúde na comunidade
}

Maria João Figueiras ${ }^{1}$

João Maroco ${ }^{2}$

Rita Monteiro ${ }^{1}$

Raul Caeiro ${ }^{1}$
${ }^{1}$ Departamento de Psicologia, Instituto Piaget. Quinta da Arreinela de Cima 2800/305. Almada Estremadura Portugal. maria.figueiras@almada. ipiaget.pt

${ }^{2}$ Unidade de Investigação em Psicologia e Saúde,

Instituto Superior de

Psicologia Aplicada.

\begin{abstract}
This study sought to confirm the structure and to investigate the psychometric properties of an experimental Portuguese version of the York Cardiac Beliefs Questionnaire (YCBQ) in a general population sample. It also set out to identify the prevalent misconceptions in the community and to assess the differences according to socio-demographic characteristics. It involved a cross-sectional survey in which both test and validation samples were collected ( $n=476$ ), including participants aged between 18 and 40, recruited via e-mail and social networks. The Confirmatory Factor Analysis on both samples suggested a shorter, three factor version of the YCBQ. Also, misconceptions differed significantly according to sociodemographic variables. The validation of the $Y C B Q$ for samples in the community constitutes an important starting point to promote research on misconceptions held in the community by specific groups, as well as to provide key points for health promotion.
\end{abstract}

Key words Cardiac misconceptions, Coronary disease, Health promotion in the community, Sociodemographic characteristics
Resumo Este estudo teve como objetivo confirmar a estrutura e investigar as propriedades psicométricas de uma versão experimental portuguesa do York Cardiac Beliefs Questionnaire numa amostra da população geral; identificar as crenças erróneas mais fortes na comunidade; e avaliar as diferenças de acordo com características sociodemográficas. Trata-se de um estudo transversal com uma amostra de teste e outra de validação, incluindo um total de 476 participantes, com idade entre 18 e 40 anos, recrutados via e-mail e nas redes sociais. A Análise Fatorial Confirmatória em ambas as amostras indicou uma versão reduzida do YCBQ de três factores. As crenças erróneas diferiram significativamente de acordo com as variáveis sociodemográficas. A validação do YCBQ para amostras da comunidade constitui um importante ponto de partida para promover a investigação sobre crenças erróneas em grupos especificos da comunidade, assim como fornecer indicadores relevantes para a promoção da saúde. Palavras-chave Crenças erróneas, Doença cardíaca, Promoção da saúde na comunidade, Características sociodemográficas 


\section{Introduction}

Cardiovascular diseases (CVDs) are still the leading causes of premature death and disability worldwide ${ }^{1}$. The most prevalent CVDs are due to atherosclerosis, which is largely caused by behavioural risk factors. Thus, CVDs are considered eminently preventable, and prevention strategies have been aimed at changing risk behaviours such as tobacco smoking, physical inactivity, unhealthy diet, and harmful use of alcohol ${ }^{1}$. Important aspects in health behaviour modification have been identified and include: effective physician-patient communication ${ }^{2}$, health literacy ${ }^{3}$, self-regulatory skills ${ }^{4}$, risk perceptions ${ }^{5}$, social and physical conditions $s^{6}$, perception of costs and benefits ${ }^{7}$, and illness beliefs ${ }^{8}$.

\section{Cardiac misconceptions}

The Common-Sense Model of Self-Regulation states that the individuals' beliefs about health are based on their previous experiences with diseases, as well as on information provided by the social context ${ }^{9}$. Information about illnesses comes from health professionals (formal diagnosis or a routine health check) and from a lay referral system (family, friends, or the media) ${ }^{10}$. This way, social messages can influence how individuals interpret illness information and the coping strategies they develop?.

People with Heart Disease (HD) hold specific beliefs about what caused it and what they should do to cope with it. But some of these beliefs are misconceptions that can lead to coping behaviours that adversely affect cardiac and overall health and outcomes ${ }^{11}$. Cardiac misconceptions have been associated with higher levels of emotional distress and invalidism ${ }^{12}$, slower recovery and reduced rate of return to work ${ }^{13}$, more re-hospitalization $s^{14}$, and poor attendance at cardiac rehabilitation ${ }^{15}$. Physical functioning is an important indicator of recovery in HD; one study found change in angina misconceptions to be the most significant predictor of patients' physical limitations at 1-year follow-up ${ }^{16}$.

Lin et al. ${ }^{17}$ found that people with a non-cardiac chronic illness may hold similar cardiac misconceptions to people with HD. On the other hand, previous studies found differences between patients and peers concerning angina, with peers holding more misconceptions than patients ${ }^{18}$. Others found evidence that the degree of match/ mismatch between the patient's and partner's perceptions of the MI is associated with a range of recovery outcomes ${ }^{19}$. Moreover, the patient-health relation can be affected by partner personality ${ }^{20}$; this evidence emphasizes the role of a patient's interpersonal world in his or hers adjustment to HD.

Yet, little is known about how people in the community hold beliefs about HD and which misconceptions are more common. Misconceptions possibly reflect beliefs shared and reinforced in the community through a reciprocating network. Interestingly, health professionals may also play a role in the reinforcement of misconceptions within the community ${ }^{21}$. Therefore, it is essential that both family and health professionals are well informed and that the latter are equipped to elicit and dispel commonly held cardiac misconceptions ${ }^{17}$. Also, cardiac misconceptions may be linked to individual characteristics such as demographic variables, as people make judgments about risk which tend to be consistent with their individual illness beliefs ${ }^{22}$.

\section{Measuring cardiac misconceptions}

Furze et al. ${ }^{18,23}$ developed the York Angina Beliefs Questionnaire (YABQ) to elicit misconceptions about angina. Their main aim was to deliver tailored education to angina patients, in order to promote adaptive coping. The YABQ revealed satisfactory psychometric properties ${ }^{23}$. The same authors developed another instrument to elicit misconceptions about causation and coping in HD, the York Cardiac Beliefs Questionnaire (YCBQ). The pilot version of the instrument ( $\mathrm{pYCBQ}$ ) consisted of 24 items pertaining to common misconceptions about living with HD drawn from patient interviews ${ }^{24}$. The authors reported satisfactory internal reliability (Cronbach's alpha $=0.85)$ and test-retest stability $(r=0.88)$ for this questionnaire after having it tested on 100 people who had undergone Coronary Artery Bypass Graft (CABG) surgery ${ }^{24}$. It was used as an outcome measure in a study about a "prehabilitation" intervention, prior to CABG surgery ${ }^{24}$.

Results at follow-up showed that patients submitted to the HeartOp programme (a self-management plan designed to facilitate coping with $\mathrm{HD}$ and $\mathrm{CABG}$ ) had lower depression and cardiac misconceptions levels, as well as a higher physical functioning level, as compared to patients in the routine preoperative nurse counselling group. Like Lin argued, content validity of the instrument was demonstrated in that study, as relationships between cardiac misconceptions 
and depression, physical limitations, and quality of life were all in the hypothesized directions ${ }^{17}$.

The pYCBQ has been primarily a clinically useful instrument that provides a brief and structured method of determining which common misconceptions a patient holds, so that nurses can target and dispel them. Hence, in the studies referred above pYCBQ answers were coded dichotomously. However, Furze et al. also created a version of the YCBQ with 22 items, organized in a three-section structure, and with a Likert-type answer scale (G. Furze, January, 2007, pers. written comm.). Angus et al. used this latter version of the YCBQ to assess whether level of cardiac misconceptions significantly differed between groups of healthcare staff based on occupation ${ }^{25}$. However, validation of this three-section version of the YCBQ is still lacking. Additionally, although some data were obtained with the pYCBQ in non-patient populations, the YCBQ was not validated yet for that type of population.

Therefore, the present study aims (1) to confirm the structure and to investigate the psychometric properties of an experimental Portuguese version of the YCBQ in a community sample; (2) to identify the stronger cardiac misconceptions; (3) to analyse differences in cardiac misconceptions as a function of socio-demographic characteristics of the participants.

\section{Method}

\section{Participants and Study Design}

This was a cross-sectional study that recruited a convenient sample of people aged between 18 and 40 years old. People were invited in workplaces and via e-mail and social networks (e.g., Facebook) to take part in an investigation about their opinions on HD. Participants completed an anonymous self-administered questionnaire in paper-and-pencil or Web form format. The recruitment was conducted in two phases: first, a test sample $(\mathrm{n}=319)$ was gathered; then, a second sample $(\mathrm{n}=157)$ was collected for validation purposes.

\section{Measures}

\section{Cardiac Misconceptions}

The York Cardiac Beliefs Questionnaire (G. Furze, January, 2007, pers. written comm.) was translated to Portuguese with permission of the authors. The original version has 22 statements, four of which are scored in reverse. The Portuguese initial version had 27 statements depicting misconceptions about cardiac illness: 22 adapted from the original English version, two adapted from a previous version of the YCBQ, and three additional ones derived from interviews with Portuguese cardiac patients and their relatives. For the purposes of the study, the quality of the translation of the 22 original items was checked through back-translation by an expert panel, taking into consideration conceptual and cultural equivalence. A pre-test was performed with males and females (18 years of age and older). The respondents were asked about any word they did not understand as well as any word or expression they found unacceptable or offensive. In this Portuguese experimental version there are no reversed items and the answers are scored in a 5-point Likert-type scale ranging from 0 ("Strongly disagree") to 4 ("Strongly agree"). Higher scores reflect stronger misconceptions. Items 1-15 refer to general misconceptions about HD, items $16-22$ are specifically about MI, and items 23-27 are concerned with angina.

\section{Socio-Demographic data \\ and lifestyle behaviours}

Participants were enquired about age, sex, level of education, family history of HD and lifestyle behaviours such as smoking and regularly exercising.

\section{Data Analysis}

\section{Psychometric Properties}

Items' psychometric sensitivity (i.e. the ability to discriminate structurally different individuals) was assessed by comparison to the normal distribution by estimation of the skewness (sk) and kurtosis $(\mathrm{ku})$ of each item's distribution. Absolute values of $\mathrm{Sk}$ and $\mathrm{Ku}$ smaller than 3 and 7 , respectively, were considered indicative of psychometric sensitivity and/or not deviating enough from the normal distribution to recommend against further psychometric analysis ${ }^{26}$. Confirmatory Factor Analysis (CFA), with Maximum Likelihood Estimation as performed by SPSS AMOS (V. 20) was used to assess the construct related validity in its factorial, convergent, and discriminant validity. Minimum sample size required for CFA for the test data was determined for 12 manifest variables and 3 latent factors with an $a$ priori estimated effect size of 0.1 , statistical power of 0.8 and type I error rate of $0.05^{27}$. A second, validation data set to confirm the external 
validity of the factor solution obtained with the test data was determined using a thumb rule of 10 observations per manifest variable ${ }^{26,28}$. Accordingly, minimum required test and validation sample sizes were 290 and 120 subjects, respectively.

The model's goodness-of-fit to the data was evaluated with the indices Chi-square over degrees of freedom $\left(\mathrm{X}^{2} / \mathrm{df}\right)$, Compative Fit Index (CFI), Goodness-of-Fit Index (GFI), and Root Mean Square Error of Approximation (RMSEA). Reference values indicative of good fit were in agreement with those proposed by Maroco ${ }^{26}$ and Byrne $^{28}: \mathrm{X}^{2} / \mathrm{df}$ less than 3, CFI and GFI greater than .9, and RMSEA lower than .05 with the $90 \%$ upper confidence limit below .1. Convergent and discriminant validity were assessed by the Average Variance Extracted (AVE) and the squared correlation between factors, as proposed by Fornell and Larcker ${ }^{29}$. Values of AVE greater than .5 were indicative of convergent validity. Pairs of AVEs greater than the squared correlations between pairs of factors were indicative of Discriminant Validity ${ }^{26}$. Item trimming was done for items with factor weights smaller than .5 and/ or with modification indices, for correlation between items and different factors from the ones originally proposed, greater than $11(\mathrm{p}<.001)$. This factor analytic approach was performed in two steps. First, the original factor structure was tested and refined in a test sample $(\mathrm{n}=319)$. Then, the refined factor structure was evaluated in a validation sample $(\mathrm{n}=157)$ by a multigroup CFA to test for Configural, Weak, and Strong factor invariance, thus evaluating the external validity of the refined factor structures. Reliability was estimated using Cronbach's $\alpha$. Values of $\alpha$ greater than .7 were considered acceptable for experimental research ${ }^{30,31}$.

The measures used in this study were approved by the Ethics Committees of the hospitals involved in the patients' studies of this research project. The participants read an Informed Consent form and agreed to participate anonymously and voluntarily.

\section{Inferential analysis}

In order to investigate possible differences in misconceptions about HD in different socio-demographic groups, independent $t$-tests and oneway ANOVAs were used. To investigate differences within-subjects, the repeated measures ANOVA was used. For comparisons as a function of age, the sample was divided by the median in two age groups (18-24 and 25-40 years). The level of education was recoded into 3 groups according to the number of years of education: 9,12 , and academic degree. Inferential statistical analysis was performed with SPSS Statistics (V. 20). Statistical significance was accepted for $\mathrm{p}<.05$.

\section{Results}

\section{Sample Characteristics}

The survey was administered in a test sample composed of 319 participants, with a mean age of 25.34 (S.D. $=5.64$ ) years, $68.7 \%$ female, and $68.3 \%$ with an academic degree. Regarding health behaviours, $75.9 \%$ of the participants were non-smokers and 59.9\% reported doing physical exercise. The results were then validated in a second sample of 157 participants, which had a mean age of 25.29 (S.D. $=5.09$ ) and was composed of $64.3 \%$ of females, $73.1 \%$ of people with an academic degree, $80.9 \%$ of non-smokers, and $59.2 \%$ of regular exercisers. Since the results obtained in these two samples were very identical they were later aggregated in an overall sample of 476 individuals. Similarly to the two smaller samples, this total sample had a mean age of 25.32 years (S.D. $=5.46$ ), and the majority of the participants were female (67.2\%), had an academic level of education (69.9\%), were non-smokers (77.5\%), and reported being physically active (59.8\%).

\section{Psychometric Data Properties}

Skewness and kurtosis for the 27 items that composed this Portuguese version of the YCBQ showed a range from -1.1 to 1.3 and -0.8 to 1.8 , respectively. None of the items presented values suggesting a severe departure from the normal distribution. According to Furze (G. Furze, January, 2007, pers. written comm.), the YCBQ defines 3 factors: Generic beliefs, MI beliefs and Angina beliefs. We tested the factorial related validity of these factors in our test sample. The tri-factorial model showed a poor fit to the variance-covariance test sample data matrix $\left(\mathrm{X}^{2} / \mathrm{df}=\right.$ 3.3; $\mathrm{CFI}=.75 ; \mathrm{CFI}=.65 ; \mathrm{RMSEA}=0.09 ; \mathrm{P}$ (rmsea $\leq 0.05)<.001$ ), with several items displaying factor weights quite smaller than .4. To improve the psychometric properties of data gathered with the YCBQ, items with factor weights smaller than .4 were removed. The reduced-YCBQ's fit to the test sample (Figure 1) was quite acceptable $\left(\mathrm{X}^{2} /\right.$ $\mathrm{df}=2.3 ; \mathrm{CFI}=.94 ; \mathrm{CFI}=.92 ; \mathrm{RMSEA}=0.066$; $\mathrm{P}($ rmsea $\leq 0.05)=.04)$. 
The reduced-YCBQ retains four items per factor with acceptable to high individual factor weights reliability $(\lambda>.4 ; \mathrm{p}<.001)$ (item's explained variance ranging from 0.19 to 0.61 ) However, AVE was . 36 for Generic beliefs, .32 for MI beliefs and .42 for Angina beliefs. Thus, convergent validity was not observed in the present sample. Low convergent validity also compromised the factors' discriminant validity (Pearson squared correlations ranges between .35 and .53). Judging from the quite large correlation between the three factors of cardiac misconceptions, we tested a second order factorial model with a single Cardiac Misconceptions factor (Figure 2).

The second order factor model presented an acceptable fit to the test sample $\left(\mathrm{X}^{2} / \mathrm{df}=2.4\right.$; $\mathrm{CFI}=.94$; CFI $=.92$; RMSEA $=0.066$; $\mathrm{P}($ rmsea $\leq 0.05)=.04)$. Cardiac misconceptions reflect strongly and significantly on Generic beliefs ( $\beta=$ $.71 ; \mathrm{p}<.001)$, MI beliefs $(\beta=.88 ; \mathrm{p}<.001)$ and Angina beliefs $(\beta=.83 ; \mathrm{p}<.001)$.

Finally, the external validity of the second order reduced-YCBQ was tested in a second validation sample $(\mathrm{n}=157)$. Chi-square differenc-

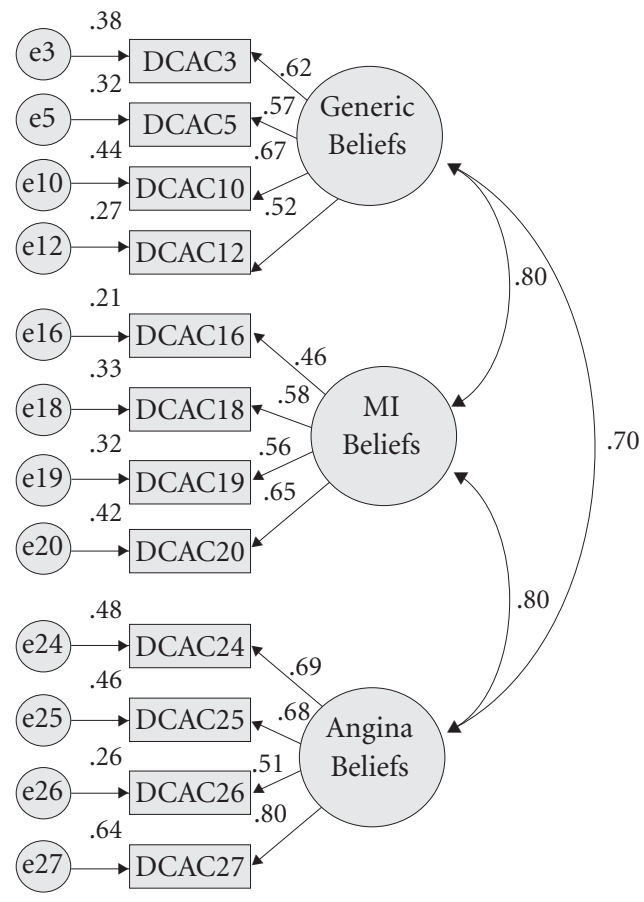

Figure 1. Reduced-YCBQ tri-factor model of Cardiac Misconceptions fitted to the test sample. es tests for free- vs. constrained models showed configural invariance (overall sample: $\mathrm{X}^{2} / \mathrm{df}$ $=1.7$ CFI $=.93$; CFI $=.92$; RMSEA $=0.039$; $\mathrm{P}($ rmsea $\leq 0.05)=.98)$, as well as measurement invariance $\left(\lambda: \Delta \mathrm{X}^{2}(9)=10.632 ; p=0.302\right)$, structural invariance $\left(\beta: \Delta \mathrm{X}^{2}(3)=2.133 ; p=0.545\right)$, and strong invariance $\left(\varepsilon: \Delta X^{2}(12)=12.646 ; p=\right.$ 0.395). Reliability, as evaluated by Cronbach's $\alpha$ was considered good for the total score, being somehow lower than desirable for MI Misconceptions. The range of Cronbach's $\alpha$ coefficients was from .60 to .81 .

\section{Analysis of cardiac misconceptions}

The stronger beliefs were related with the need to avoid stress and with the danger of arguing (Table 1). Ranging from 0 to 4 , the mean of the total score was 1.91 ( $\mathrm{SD}=0.50)$, indicating a moderate overall level of misconceptions. The mean scores in each section were subjected to a within-subjects comparison through the use of a repeated measures ANOVA with Greenhouse-Geisser correction, since sphericity could not be assumed. There were significant differences between the three sections $(F(1.9,922.51)=$

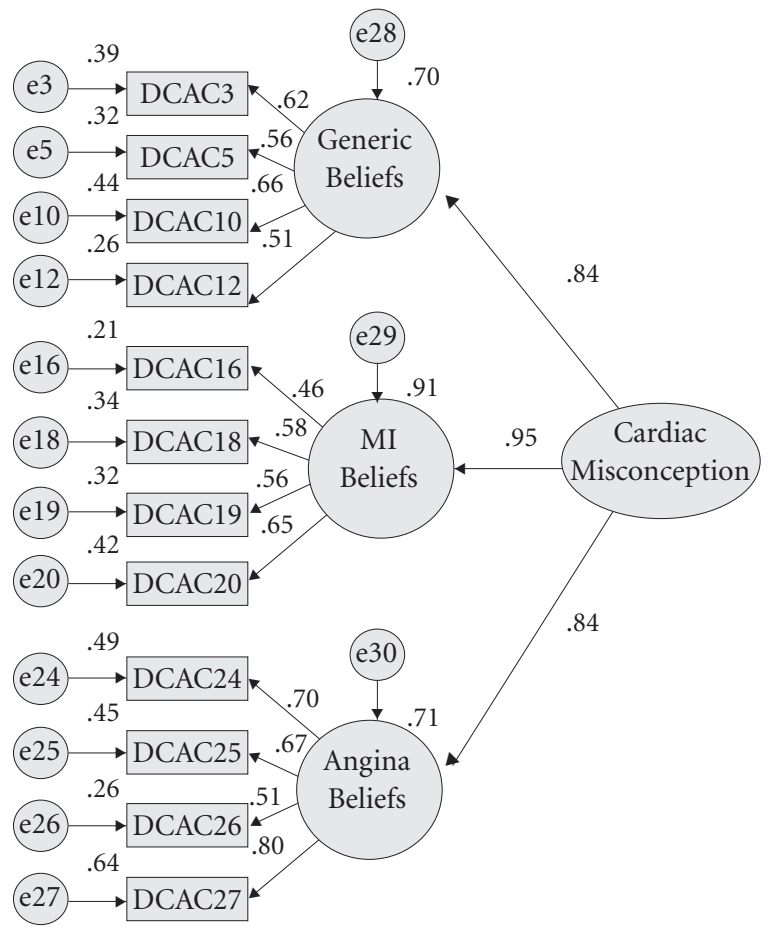

Figure 2. Reduced second order factor model of Cardiac Misconceptions fitted to the test sample. 
328.37; $\mathrm{p}<.0001, \eta^{2} \mathrm{p}=.409$, observed power $=$ 1.00). Pairwise comparisons indicated significant differences between all three sections $(p<.05)$ : the Generic misconceptions had the strongest mean score, followed by the Angina section, and the MI section had the lowest mean.

\section{Differences in misconceptions according to socio-demographic variables and lifestyle behaviours}

The scores of the sections of the scale were compared according to sex, age group, educational level, family history of HD, and lifestyle behaviours (smoking and exercise) (Table 2). Regarding sex, there were significant differences on the MI section. Men had stronger levels of misconceptions about MI than women $(\mathrm{t}(474)=$ $-2.84, p=.005 ; r=0.129)$ As a function of age, a significant difference between the two age groups was found in misconceptions about MI, the older group reporting a higher level of misconceptions than the younger one $(\mathrm{t}(474)=-2.67, p=.009 ; r$ $=0.121)$. There were also significant differences on all three misconceptions subscales as a func- tion of educational level (generic misconceptions: $\mathrm{F}(2,472)=16.69, p<.0001, \eta^{2} \mathrm{p}=0.66 ; \mathrm{MI}$ misconceptions: $\mathrm{F}(2,472)=13.94, p<.0001 ; \eta^{2} \mathrm{p}$ $=0.06$; angina misconceptions: $\mathrm{F}(2,472)=11.30$, $\left.p<.0001 ; \eta^{2} p=0.046\right)$. Post-hoc Tukey indicated that participants with an academic degree had significantly weaker misconceptions than those with 9 or 12 years of education. The same analysis was also performed for family history of $\mathrm{HD}$ and lifestyle behaviours (smoking and exercise). No significant differences were found in any of the misconceptions subscales as a function of these variables.

\section{Discussion}

This study aimed to confirm the three section structure and investigate the psychometric properties of the YCBQ in a Portuguese community sample of young adults. It also intended to explore how cardiac misconceptions differ according to socio-demographic characteristics. Confirmatory Factor Analysis (CFA) indicated that a reduced version of the $\mathrm{YCBQ}$, maintain-

Table 1. Reduced-YCBQ items mean scores $(\mathrm{N}=476$, range $0-4)$.

\begin{tabular}{|c|c|c|c|}
\hline Section & Item (English/Portuguese) & $\mathbf{M}$ & SD \\
\hline \multirow[t]{4}{*}{$\begin{array}{l}\text { Generic } \\
\text { Beliefs }\end{array}$} & $\begin{array}{l}\text { Rest is the best medicine for heart conditions / O descanso é o melhor remédio para as } \\
\text { doenças de coração }\end{array}$ & 2.02 & 1.09 \\
\hline & $\begin{array}{l}\text { It is dangerous for people who have heart disease to argue / Para as pessoas que sofrem } \\
\text { do coração é perigoso ter discussões }\end{array}$ & 2.65 & .89 \\
\hline & $\begin{array}{l}\text { Any sort of excitement could be bad if you have heart disease / Qualquer tipo de } \\
\text { excitação pode ser má se a pessoa sofre de doenças do coração }\end{array}$ & 1.89 & 1.02 \\
\hline & $\begin{array}{l}\text { People who have heart disease should always avoid stress / As pessoas que sofrem do } \\
\text { coração devem sempre evitar o stress }\end{array}$ & 2.86 & .78 \\
\hline \multirow{5}{*}{$\begin{array}{c}\text { MI } \\
\text { Beliefs }\end{array}$} & It is dangerous for people who have had a heart attack to exercise / Para as pessoas que & 1.35 & .94 \\
\hline & tiveram um ataque cardíaco é perigoso fazer exercício & & \\
\hline & $\begin{array}{l}\text { After a heart attack life is always worse than before / Depois de um ataque cardíaco a } \\
\text { vida é sempre pior do que era antes }\end{array}$ & 1.54 & .95 \\
\hline & $\begin{array}{l}\text { A heart attack makes a weak area in the heart that can easily rupture / Um ataque } \\
\text { cardíaco cria uma área muito frágil na parede do coração que pode facilmente romper }\end{array}$ & 2.04 & .83 \\
\hline & $\begin{array}{l}\text { Once you have had a heart attack you are bound to have another / Quem teve um } \\
\text { ataque cardíaco está condenado a ter outro }\end{array}$ & 1.53 & .99 \\
\hline \multirow[t]{4}{*}{$\begin{array}{l}\text { Angina } \\
\text { Beliefs }\end{array}$} & $\begin{array}{l}\text { Any sort of excitement is bad for people with angina / Qualquer tipo de excitação é má } \\
\text { para as pessoas com angina de peito }\end{array}$ & 1.81 & .83 \\
\hline & $\begin{array}{l}\text { People with angina should not live life to the full / As pessoas que sofrem de angina de } \\
\text { peito não podem viver a vida ao máximo }\end{array}$ & 1.47 & .84 \\
\hline & $\begin{array}{l}\text { Every bout of angina causes permanent damage to the heart / Cada episódio de angina } \\
\text { de peito causa danos permanentes no coração }\end{array}$ & 2.06 & .75 \\
\hline & $\begin{array}{l}\text { People with angina should avoid being active / As pessoas que sofrem de angina de } \\
\text { peito devem evitar ser muito activas }\end{array}$ & 1.68 & .78 \\
\hline
\end{tabular}


Table 2. Mean values for cardiac misconception and risk perceptions according to sex, age, educational level, family history of heart disease, and lifestyle behaviours (smoking and exercise).

\begin{tabular}{|c|c|c|c|}
\hline & $\begin{array}{c}\text { Generic } \\
\text { Beliefs } \\
(0-4)\end{array}$ & $\begin{array}{c}\text { MI } \\
\text { Beliefs } \\
(0-4)\end{array}$ & $\begin{array}{c}\text { Angina } \\
\text { Beliefs } \\
(0-4)\end{array}$ \\
\hline \multicolumn{4}{|l|}{ Sex } \\
\hline Female & $\begin{array}{c}2.36 \\
(0.69)\end{array}$ & $\begin{array}{c}1.56 \\
(0.63)\end{array}$ & $\begin{array}{c}1.73 \\
(0.62)\end{array}$ \\
\hline Male & $\begin{array}{c}2.35 \\
(0.63)\end{array}$ & $\begin{array}{c}1.73 \\
(0.64)\end{array}$ & $\begin{array}{c}1.82 \\
(0.51)\end{array}$ \\
\hline \multicolumn{4}{|l|}{ Age group } \\
\hline $18-24$ & $\begin{array}{c}2.34 \\
(0.65)\end{array}$ & $\begin{array}{c}\mathbf{1 . 5 5} \\
(0.61)\end{array}$ & $\begin{array}{c}1.72 \\
(0.60)\end{array}$ \\
\hline $25-40$ & $\begin{array}{c}2.38 \\
(0.70)\end{array}$ & $\begin{array}{c}1.71 \\
(0.67)\end{array}$ & $\begin{array}{c}1.81 \\
(0.58)\end{array}$ \\
\hline \multicolumn{4}{|l|}{ Educational Level } \\
\hline$\leq 9$ years & $\begin{array}{c}2.63^{\mathrm{a}} \\
(0.60)\end{array}$ & $\begin{array}{c}\mathbf{2 . 0 3} \mathbf{3}^{\mathrm{a}} \\
(0.74)\end{array}$ & $\begin{array}{c}1.97^{a} \\
(0.56)\end{array}$ \\
\hline$\leq 12$ years & $\begin{array}{c}2.62^{\mathrm{a}} \\
(0.66)\end{array}$ & $\begin{array}{c}\mathbf{1 . 7 8}^{\mathrm{a}} \\
(0.62)\end{array}$ & $\begin{array}{c}1.94^{\mathrm{a}} \\
(0.56)\end{array}$ \\
\hline Academic Degree & $\begin{array}{l}2.24^{\mathrm{b}} \\
(0.65)\end{array}$ & $\begin{array}{c}1.52^{\mathrm{b}} \\
(0.61)\end{array}$ & $\begin{array}{c}1.67^{b} \\
(0.58)\end{array}$ \\
\hline \multicolumn{4}{|l|}{ Family history } \\
\hline Yes & $\begin{array}{c}2.32 \\
(0.64)\end{array}$ & $\begin{array}{c}1.55 \\
(0.62)\end{array}$ & $\begin{array}{c}1.70 \\
(0.63)\end{array}$ \\
\hline No & $\begin{array}{c}2.38 \\
(0.69)\end{array}$ & $\begin{array}{c}1.66 \\
(0.65)\end{array}$ & $\begin{array}{c}1.79 \\
(0.56)\end{array}$ \\
\hline \multicolumn{4}{|l|}{ Smoker } \\
\hline Yes & $\begin{array}{c}2.44 \\
(0.73)\end{array}$ & $\begin{array}{c}1.68 \\
(0.64)\end{array}$ & $\begin{array}{c}1.84 \\
(0.59)\end{array}$ \\
\hline No & $\begin{array}{c}2.33 \\
(0.65)\end{array}$ & $\begin{array}{c}1.60 \\
(0.64)\end{array}$ & $\begin{array}{c}1.73 \\
(0.59)\end{array}$ \\
\hline \multicolumn{4}{|l|}{ Exercise } \\
\hline Yes & $\begin{array}{c}2.34 \\
(0.68)\end{array}$ & $\begin{array}{c}1.60 \\
(0.66)\end{array}$ & $\begin{array}{c}1.72 \\
(0.58)\end{array}$ \\
\hline No & $\begin{array}{c}2.38 \\
(0.66)\end{array}$ & $\begin{array}{c}1.63 \\
(0.62)\end{array}$ & $\begin{array}{c}1.80 \\
(0.59)\end{array}$ \\
\hline
\end{tabular}

Significant differences, as revealed by $\mathrm{t}$ - tests, are presented in Bold. Means sharing the same subscript are not significantly different according to one-way ANOVA.

ing the original three section structure, had an acceptable fit to the data. The stronger misconceptions observed were related with the need to avoid stress and with the danger of arguing. Generic misconceptions were stronger than angina and MI beliefs. Sex and age group influenced MI beliefs and education level influenced all three types of cardiac misconceptions.

To our knowledge, this is the first report of a CFA being done with the YCBQ. These results provide empirical support to the new YCBQ structure, although they indicate that in commu- nity settings a reduced version is more psychometrically sound. Having separate sections for generic, MI, and angina misconceptions allows a selective application of the specific sections that may be relevant in a certain context.

This reduced version of the YCBQ evaluates very similar misconceptions to those evaluated by the previous versions. The reduced-YCBQ has seven overlapping items with the pYCBQ. In a previous study with British and Taiwanese CHD patients, each of these seven misconceptions was endorsed by at least $23.5 \%$ of the British and $73.0 \%$ of the Taiwanese patients ${ }^{32}$. The remaining items of the reduced-YCBQ do not correspond exactly to items in the PYCBQ, but depict similar underlying beliefs. In all three sections, there are items related to the avoidance of stress, excitement, and physical activity. In addition, the MI section deals with negative beliefs about the future and the angina section contains one item associating this condition with permanent damage to the heart. It is important to improve the measurement of such beliefs, since previous studies with cardiac patients reported them to be detrimental for recovery and management of $\mathrm{HD}^{11}$. Patients who attribute their HD to stress are less likely to tackle their behavioural risk factors $^{33}$ and more likely to report a worse health status eight years after an $\mathrm{MI}^{34}$. Beliefs in the dangerousness of physical activity possibly lead to an attitude of "invalidism" and increase cardiovascular risk due to fitness decline ${ }^{35}$. Negative disproportionate views about the consequences of MI or angina are likely to reflect or promote a sense of uncontrollability and helplessness that may foster depression and hinder the adoption of active coping strategies ${ }^{36-38}$.

The present results indicate that these detrimental misconceptions are also commonly shared in the community, particularly beliefs about the need to avoid stress and arguing. One previous study had investigated misconceptions held by peers of angina patients, but the focus was specific to angina beliefs ${ }^{18}$. More recently, Lin et al. ${ }^{17}$ also investigated the beliefs of Taiwanese people suffering from other chronic illnesses besides HD, providing the first data about the generic cardiac misconceptions held by people without a diagnosis of HD. Both studies reported that misconceptions about exercise and stress were among the most frequent. However, participants in those samples belonged to an older age group than participants in our study, and were likely to have had more experience with illness and the health system. This is the first report of 
cardiac misconceptions held by younger healthy adults and it indicates that some misconceptions are in fact widely shared in the community and not only in patient settings. Cardiac misconceptions may hinder the effectiveness of adequate health information delivered via health campaigns. As pointed out by the Common-Sense Model $^{9}$, social influences need to be acknowledged when planning interventions to increase illness knowledge, as harmful misconceptions reinforced in society will be resistant to change.

In the present study, participants who were male, older, or did not have an academic degree had stronger misconceptions, suggesting it might be particularly relevant to address the cardiac misconceptions held by these groups. Lin et al. ${ }^{32}$ had also found higher misconceptions among older participants in a study comparing Taiwanese and British patients. However, among the Taiwanese group of patients women had higher misconceptions than men, while in the British sample no difference was found. The inconsistency between these findings regarding sex differences may be related to cultural aspects and should be clarified.

These results support the relevance of developing community interventions aimed at dispelling the most common cardiac misconceptions. They also provide an indication of the groups that have more need of intervention: men, older people, and people with lower education. We recommend that public health campaigns on HD include information directly contradicting the most common misconceptions. Furze team have already developed guidelines to dispel cardiac misconceptions in patient settings. Intervention programs such as the Angina Plan ${ }^{39}$ and the Heart Manual ${ }^{40}$ have proved successful in altering patients' misconceptions. Both programs include specific materials aimed at correcting erroneous beliefs similar to the ones on the YCBQ. One possible intervention would be to adapt those materials to elaborate information that could be included in brochures about CVDs; such brochures could be part of a health campaign on HD. Being briefer, this version of the YCBQ is more amenable to use in the general population or in large groups. In more direct interventions at the primary care settings, the reduced-YCBQ is easier to administrate as a screening tool to identify and dispel the misconceptions held by a group of persons. Besides its clinical usefulness, the YCBQ is also a valuable resource for further research. Having a briefer version of the YCBQ, with satisfactory psychometric properties validated in a non-patient sample, may enable the advancement of the investigation of cardiac misconceptions in a public health perspective. For instance, evidence of a relation between cardiac misconceptions and adoption of inadequate health behaviours by healthy people is still lacking. Additionally, the YCBQ constitutes a useful means of testing the efficacy of the interventions developed in the community.

Nonetheless, some limitations need to be acknowledged. First, the cross-sectional nature of this study prevents conclusions about causality. Longitudinal study designs could overcome this limitation and would also allow analysing how stable misconceptions are. Second, the majority of the participants were recruited on-line, which may have biased the sample towards being younger and having a higher educational level and better computer skills. However, from the outset we intended to collect a young sample and expected this population group to be at ease with online technology. Lastly, restricting the age of inclusion to less than 40 years may limit the generalizability of the results. It would be important to gather data on beliefs held by people belonging to a wider age span, as different cohorts are likely to differ in their experience and access to information on HD.

In conclusion, the results of this study support the necessity of further research on lay beliefs about HD, as incorrect beliefs seem to be commonly shared in society. The reduced-YCBQ constitutes an important starting point to promote research on misconceptions held in the community. Since that reinforces maladaptive beliefs, concordance with professional advice may be replaced over time with compliance with societal beliefs ${ }^{17}$. Therefore, if common misconceptions are not targeted, the increasing investment in HD prevention may prove ineffective. It is urgent to elicit and dispel cardiac misconceptions in order to promote realistic views of HD within society, thus adjusting risk perception, promoting healthier lifestyles, and reducing the incidence of HD. 


\section{Collaborations}

MJ Figueiras contributed to the conception, drafting of the text, interpretation of data analysis, and revision of the text; J Maroco contributed to data analysis, interpretation of data and drafting of the methods and results section; $\mathrm{R}$ Monteiro contributed to drafting of the text, interpretation of data analysis, and revision of the final text; R Caeiro contributed to drafting of the text, interpretation of data analysis, and revision of the final text.

\section{Acknowledgments}

We would like to acknowledge the assistance of Professor Gill Furze as consultant of this research. This work was supported by FEDER through COMPETE; and FCT - Fundação para a Ciência e Tecnologia [Reference - PTDC/PSI-PCL/ 112503/2009].

\section{References}

1. World Health Organization (WHO). Global Atlas on Cardiovascular Disease Prevention and Control. Geneva: WHO, World Heart Federation, World Stroke Organization; 2011.

2. Stewart MA. Effective physician-patient communication and health outcomes: A review. Can Med Assoc J 1995; 152(9):1423-1433.

3. Levasseur M, Carrier A. Do rehabilitation professionals need to consider their clients' health literacy for effective practice? Clin Rehabil 2010; 24(8):756-765.

4. Sniehotta F, Scholz U, Schwarzer R. Bridging the intention-behaviour gap: Planning, self-efficacy, and action control in the adoption and maintenance of physical exercise. Psychol Health 2005; 20(2):143-160.

5. Webster R, Heeley E. Perceptions of risk: understanding cardiovascular disease. Risk Manag 2010; 3:49-60.

6. Backer T, Rogers E, Sopory P. Designing Health Communication Campaigns: What Works? Newbury Park: Sage Publications; 1992.

7. Maiman LA, Becker MH. The Health Belief Model: Origins and correlates in psychological theory. Health Educ Monographs 1974; 2(4):336-353.

8. Juergens MC, Seekatz B, Moosdorf RG, Petrie KJ, Rief $\mathrm{W}$. Illness beliefs before cardiac surgery predict disability, quality of life, and depression 3 months later. J Psychosom Res 2010; 68(6):553-560.

9. Leventhal H, Brissette I, Leventhal A. The common-sense model of self-regulation of health and illness. In: Cameron LD, Leventhal $\mathrm{H}$, editors. The Self-Regulation of Health and Illness Behaviour. London: Routledge; 2003. p. 42-65.

10. Odgen J. Health Psychology: A textbook. $4^{\text {th }}$ edition. Maidenhead: Open University Press; 2007.

11. Furze G. Cardiac misconceptions: A problem in need of treatment? Pract Cardiovasc Risk Manag 2007; 5:13-15.

12. Wynn A. Unwarranted emotional distress in men with Ischaemic Heart Disease (IHD). Med J Aust 1967; 2(19):847-851.

13. Maeland JG, Havik OE. Psychological predictors for return to work after a myocardial infarction. J Psychosom Res 1987; 31(4):471-481.

14. Maeland JG, Havik OE. After the myocardial infarction: A medical and psychological study with special emphasis on perceived illness. Scand J Rehabil Med 1989; 22:1-87.

15. Cooper AF, Weinman J, Hankins M, Jackson G, Horne R. Assessing patients' beliefs about cardiac rehabilitation as a basis for predicting attendance after acute myocardial infarction. Heart 2007; 93(1):53-58.

16. Furze G, Lewin RJ, Murberg T, Bull P, Thompson DR. Does it matter what patients think? The relationship between changes in patients' beliefs about angina and their psychological and functional status. J Psychosom Res 2005; 59(5):323-329.

17. Lin Y-P, Wang T-J, Tung H-H, Furze G. Coronary heart disease beliefs and misconceptions among cardiac patients and people with chronic illness. Open J Nurs 2012; 2(1):1-7.

18. Furze G, Roebuck A, Bull P, Lewin RJ, Thompson DR. A comparison of the illness beliefs of people with angina and their peers: A questionnaire study. BMC Cardiovascular Disorders 2002; 2:4. 
19. Figueiras MJ, Weinman J. Do similar patient and spouse perceptions of myocardial infarction predict recovery? Psychol Health 2003; 18(2):201-216.

20. Karademas EC, Tsaousis I. The relationship of patient and spouse personality to cardiac patients' health: Two observational studies of mediation and moderation. Ann Behav Med 2014; 47(1):79-91.

21. Coulson RL, Feltovich PJ, Spiro RJ. Foundations of a misunderstanding of the ultrastructural basis of myocardial failure: A Reciprocation network of oversimplifications. J Med Philos 1989; 14(2):109-146.

22. Gholizadeh L, Davidson P, Salamonson Y, Worrall-Carter L. Theoretical considerations in reducing risk for cardiovascular disease: Implications for nursing practice. J Clin Nurs 2010; 19(15-16):2137-2145.

23. Furze G, Bull P, Lewin RJ, Thompson DR. Development of the York Angina Beliefs Questionnaire. J Health Psychol 2003; 8(3):307-315.

24. Furze G, Dumville JC, Miles JN, Irvine K, Thompson DR, Lewin RJ. "Prehabilitation" prior to CABG surgery improves physical functioning and depression. Int $J$ Cardiol 2009; 132(1):51-58.

25. Angus N, Patience F, MacLean E, Corrigall H, Bradbury I, Thompson DR, Atherton I, Leslie SJ. Cardiac misconceptions in healthcare workers. Eur J Cardiovasc Nurs 2012; 11(4):396-401.

26. Maroco J. Análise Estatística com o PASW Statistics (exSPSS). Pêro Pinheiro: Report Number; 2010.

27. Westland JC. Lower bounds on sample size in structural equation modeling. Electron Commer Res App 2010; 9(6):476-487.

28. Byrne BM. Structural Equation Modeling With AMOS: Basic Concepts, Applications, and Programming. New York: Taylor \& Francis/Routledge; 2011.

29. Fornell C, Larcker DF. Structural equation models with unobservable variables and measurement error: Algebra and statistics. J Marketing Res 1981; 18(3):382-388.

30. Nunnally JC. Psychometric Theory. $2^{\text {nd }}$ edition. New York: McGraw-Hill; 1978.

31. Maroco J, Garcia-Marques T. Qual a fiabilidade do alfa de Cronbach? Questões antigas e soluções modernas? Laboratório de Psicologia 2006; 4(1):65-90.
32. Lin Y-P, Furze G, Spilsbury K, Lewin RJ. Misconceived and maladaptive beliefs about heart disease: A comparison between Taiwan and Britain. J Clin Nurs 2009; 18(1):46-55.

33. Weinman J, Petrie KJ, Sharpe N, Walker S. Causal attributions in patients and spouses following first-time myocardial infarction and subsequent life changes. Brit J Health Psych 2000; 5:263-273.

34. Affleck G, Tennen H, Croog S, Levine S. Causal attribution, perceived benefits, and morbidity after a heart attack: An 8-year study. J Consult Clin Psychol 1987; 55(1):29-35.

35. Newman S. The psychological perspective: A professional view. Heart 2003; 89(Supl. 2):16-18.

36. Petrie KJ, Weinman J, Sharpe N, Buckley J. Role of patients' view of their illness in predicting return to work and functioning after myocardial infarction: Longitudinal study. BMJ 1996; 312(7040):1191-1194.

37. Nes LS, Segerstrom SC. Dispositional optimism and coping: A meta-analytic review. Pers Soc Psychol Rev 2006; 10(3):235-251.

38. Scheier MF, Matthews KA, Owens JF, Magovern GJ Sr, Lefebvre RC, Abbott RA, Carver CS. Dispositional optimism and recovery from coronary artery bypass surgery: The beneficial effects on physical and psychological well-being. J Pers Soc Psychol 1989; 57(6):10241040.

39. Lewin RJ, Furze G, Robinson J, Griffith K, Wiseman S, Pye M, Boyle R. A randomised controlled trial of a self-management plan for patients with newly diagnosed angina. Brit J Gen Pract 2002; 52(476):194-201.

40. Lewin B, Robertson I H, Cay EL, Irving JB, Campbell M. Effects of self-help post-myocardial-infarction rehabilitation on psychological adjustment and use of health services. Lancet 1992; 339(8800):1036-1040.

Artigo apresentado em 30/07/2014

Aprovado em 28/09/2014

Versão final apresentada em 30/09/2014 